Tersedia online di: http://ejournal-balitbang.kkp.go.id/index.php/jra

\title{
PERFORMA BENIH TERIPANG PASIR, Holothuria scabra DARI SUMBER INDUK YANG BERBEDA
}

\author{
Sari Budi Moria Sembiring\#, Ida Komang Wardana, dan Haryanti \\ Balai Besar Penelitian dan Pengembangan Budidaya Laut
}

\begin{abstract}
ABSTRAK
Upaya pengembangan perbenihan teripang pasir bagi kelestarian populasi di alam dan pengembangan budidaya patut dilakukan. Upaya ini diperlukan mengingat semakin intensifnya penangkapan teripang di alam yang dapat menimbulkan terganggunya kelestarian populasi ini. Tujuan dari penelitian ini adalah untuk mengevaluasi performa pertumbuhan benih teripang pasir, mendapatkan informasi keragaman genetik dan mengestimasi laju inbreeding dari 3 sumber induk teripang yang berbeda. Tiga sumber induk berasal dari perairan Bali, Sulawesi Selatan, dan Maluku Tenggara masing-masing sebanyak 20 ekor dianalisis menggunakan mikrosatelit (SSR/Simple Sequence Repeats) dengan 3 lokus, yaitu Hsc-28; Hsc-49 dan Hsc-59. Proses pembenihan mengikuti pedoman teknis yang sudah ada dengan beberapa modifikasi. Hasil yang diperoleh menunjukkan bahwa panjang dan bobot benih umur 6 bulan yang dihasilkan dari induk Maluku Tenggara relatif lebih tinggi $(5,67 \pm 0,76 \mathrm{~cm} ; 13,26 \pm 5,63 \mathrm{~g})$ dibandingkan dengan benih dari induk Sulawesi Selatan $(4,75 \pm 0,91 \mathrm{~cm} ; 6,3 \pm 2,22 \mathrm{~g})$ dan Bali $(4,85 \pm 0,64 \mathrm{~cm} ; 6,2 \pm 3,6 \mathrm{~g})$. Hasil analisis mikrosatelit menunjukkan bahwa keragaman genetik induk teripang pasir dari ke tiga populasi tidak berbeda nyata. Hal ini berdasarkan nilai differensiasi genetik $\left(\mathrm{F}_{\mathrm{ST}}=0,2475\right.$ atau $24,75 \%$. Laju nilai inbreeding dalam populasi induk teripang pasir cukup tinggi $\left(\mathrm{F}_{\mathrm{IT}}=0,4237\right.$ atau $42,37 \%$ dibandingkan dengan laju inbreeding antar populasi $\left(F_{15}\right)$ adalah 0,2342 atau $23,42 \%$
\end{abstract}

KATA KUNCl: performa benih; variasi genetik; induk; mikrosatelit; teripang pasir

ABSTRACT: Performance of sea cucumber, Holothuria scabra juvenile from different sources of brroodstock. By: Sari Budi Moria Sembiring, Ida Komang Wardana, and Haryanti

The effort of sea cucumber seed production for culture development have to be carried out. This effort is also required due to the intensive exploration of sea cucumber in the nature which could threaten of its sustainability. The aims of this research is to evaluate sea cucumber juveniles growth performance, to obtain the information on genetic variation, and to estimate the rate of inbreeding from three different sea cucumber broodstock sources. Three sources of sea cucumber were collected from Bali, South Sulawesi, and Southeast M oluccas. The total of 20 pcs from each area were analyzed by microsatellite (SSR Simple Squence Repeat) with 3 locus namely Hsc-28; Hsc-49 dan Hsc-59. Hatchery production of sea cucumber seed followed the existing manual with some modifications. Result of the experiment showed that the length and weight of 6 months old juveniles produced by Southeast Moluccas's broodstock were relatively higher $(5.67 \pm 0.76 \mathrm{~cm} ; 13.26 \pm 5.63 \mathrm{~g})$ compared to the juveniles produced by South Sulawesi's broodstock $(4.75 \pm 0.91 \mathrm{~cm} ; 6.30 \pm 2.22 \mathrm{~g}$ ) and Bali's broodstock ( $4.85 \pm 0.64 \mathrm{~cm} ; 6.2 \pm 3.6 \mathrm{~g})$. Results of microsatellite analysis showed that genetic variation of the threebroodstock populations was not significant different. It is based on the genetic differentiation value $\mathrm{F}_{\mathrm{ST}}=\mathbf{0 . 2 4 7 5}$ or $24.75 \%$ The result of inbreeding rate within the broodstock of sea cucumber population was high $\left(\mathrm{F}_{\mathrm{IT}}=0.4237\right.$ or $42.37 \%$ compare to the rate value of inter population $\left(\mathrm{F}_{\mathrm{IS}}=0.2342\right.$ or $23.42 \%$

KEYWORDS: broodstock; genetic variation; juvenile; microsatellite; performance; sea cucumber

\section{PENDAHULUAN}

Berkurangnya sumber daya hewan akuatik alam menimbulkan kekhawatiran masyarakat dan

\footnotetext{
* Korespondensi: Balai Besar Penelitian dan Pengembangan Budidaya Laut. Jl. Br. Gondol Kec. Gerokgak Kab. Buleleng, Kotak Pos 140, Singaraja, Bali 81101, Indonesia.

Tel.: + (0362) 92272

E-mail: moriasembiring@ yahoo.co.id
}

pemerhati lingkungan, serta sumber daya. Kekhawatiran ini tidak hanya menyangkut aspek ekonomi, tetapi juga karena dampak yang ditimbulkannya, seperti perubahan keseimbangan ekosistem dan penurunan populasi berbagai plasma nutfah. Penyusutan biodiversitas hewan akuatik alam (stock depletion) sebenarnya disebabkan oleh cepatnya tingkat pengurangan individu oleh eksploitasi 
berlebih, sehingga populasinya tidak mempunyai waktu dan kesempatan untuk berkembang biak, mengganti anggota populasi yang hilang (self-recovery) (Uthicke et al., 2009).

Teripang pasir, Holothuria scabra merupakan salah satu kelompok anggota Echinodermata yang juga merupakan salah satu contoh hewan akuatik yang mungkin mengalami penyusutan keanekaragaman genetik karena tingginya tingkat eksploitasi bahkan di beberapa daerah telah mengalami lebih tangkap (over fishing). Teripang pasir dapat mencapai ukuran hingga 1 kg/ekor, namun diperlukan waktu 2-3 tahun untuk mencapainya. Ukuran konsumsi umumnya antara 150250 g/ekor atau rata-rata 200 g/ekor dan dibutuhkan 20-24 bulan untuk mencapai ukuran tersebut. Habitat yang ditempati umumnya adalah perairan laut dangkal. Kenyataan ini memperburuk kondisi populasinya jika dilakukan penangkapan yang terus-menerus.

Penurunan jumlah stok teripang yang drastis justru terjadi di negara-negara yang tidak atau sedikit sekali mengonsumsi teripang, seperti Indonesia, Thailand, Filipina, Maldives, dan negara tropis lainnya (Akamine, 2000; Bussarawit \& Thongtham, 1999; Reichenbach \& Holloway, 1995). Sejak tahun 1987, jumlah teripang yang ditangkap di seluruh dunia diperkirakan 120.000 ton per tahun, dan pasokan terbesar berasal dari Indonesia dengan negara pengimpor terbesar adalah Hongkong dan Singapura, dan seluruhnya merupakan stok alam (Conand \& Byrne, 1993).

Budidaya teripang merupakan salah satu alternatif untuk mengantisipasi penurunan produksi akibat tangkap lebih (over fishing). Sebagai mata rantai utama dalam sistem produksi teripang, penyediaan benih masih merupakan faktor pembatas baik dalam hal kuantitas maupun kualitasnya. Balai Besar Penelitian dan Pengembangan Budidaya Laut (BBPPBL) GondolBali pada tahun 1994-1998 telah merintis perbenihan teripang dengan melakukan serangkaian penelitian dari pematangan gonad dan pemijahan induk, serta pemeliharaan larva hingga juvenil (Makatutu et al., 1993; Moria et al., 1997; Moria et al., 1998).

Teknik produksi benih teripang di perbenihan dipengaruhi oleh faktor lingkungan seperti suhu, variasi pakan dan kandungan nutrisinya, dan karakter genetik induk teripang. Beberapa peneliti menyatakan bahwa diversitas genetik harus dipertahankan dalam proses pembenihan, karena reduksi atau peluruhan karakter genetik akan menyebabkan beberapa gen pengontrol sifat atau karakter tertentu menjadi hilang pada turunannya. Penurunan kualitas genetik secara umum ditandai dengan sifat-sifat seperti pertumbuhan lambat, tingkat kematian tinggi, kematangan gonad pada usia dini, dan ukuran individu yang kecil (Leary et al., 1985; Sugama et al., 1988). Ada beberapa metode yang dapat dilakukan untuk mengetahui keragaman genetik pada teripang, salah satunya menggunakan teknik mikrosatelit. Mikrosatelit merupakan marka genetik yang bermanfaat karena bersifat kodominan, dapat mendeteksi keragaman alel pada tingkat tinggi, serta mudah dan tidak terlalu mahal untuk dianalisis dengan menggunakan polymerase chain reaction (PCR) (Desvignes et al., 2001; Launey \& Hedgecock, 2001).

Eksploitasi teripang di alam yang sangat tinggi menyebabkan ukuran induk relatif kecil dibandingkan beberapa tahun sebelumnya (Moria et al., 1997). Oleh karena itu, dilakukan analisis karakter genetik dari sumber induk yang berbeda, serta dilakukan juga pengamatan terhadap performa benih yang dihasilkan (pertumbuhan panjang dan bobot). Hal ini dilakukan dalam rangka memperoleh benih unggul secara fenotipe dan genotipe.

\section{BAHAN DAN METODE}

Penelitian dilakukan di Balai Besar Penelitian dan Pengembangan Budidaya Laut, Gondol-Bali. Tahapan penelitian yang dilakukan meliputi:

\section{Pembenihan Teripang Pasir}

Pembenihan teripang dimulai dengan pengumpulan induk dari lokasi yang berbeda, yaitu: Desa Pejarakan, Kabupaten Buleleng, Bali; Desa Lawallu, Kecamatan Soppeng, Kabupaten Barru, Sulawesi Selatan; dan Desa Ngilngof, Pulau Kei Kecil, Kabupaten M aluku Tenggara. Induk dipijahkan dengan sistem kejutan suhu menggunakan heater sehingga suhu air dalam bak pemijahan mencapai $30^{\circ} \mathrm{C}$. Setiap induk dari lokasi yang berbeda dipijahkan dan larva yang dihasilkan dipelihara selama enam bulan sampai mencapai benih berukuran $4-5 \mathrm{~cm}$. Jenis pakan dan teknik pemeliharaan larva sesuai dengan pedoman teknis yang sudah ada (Sembiring et al., 2004), namun dengan modifikasi khususnya pada jenis pakan yang diberikan pada saat pendederan benih. Selama pendederan benih teripang, jenis pakan yang diberikan adalah pakan alami berupa diatom bentos yang didominasi oleh famili Melosiraceace; Naviculaceae; Nitzschiaceae, serta zooplankton dari famili Acartiidae (bentos) yang dipadatkan.

Diatom bentos yang bersumber dari air laut, dikultur dalam bak beton ukuran 4,0 m x 2,0 m x $0,6 \mathrm{~m}$ yang dilengkapi dengan jaring segi empat ukuran $1,0 \mathrm{~cm} \times 0,7 \mathrm{~cm} \times 0,5 \mathrm{~cm}$. Untuk menumbuhkan diatom (bentos), dilakukan pemupukan menggunakan pupuk TSP : ZA : Urea dengan perbandingan 1:1:1. Selama penumbuhan diatom bentos, diterapkan sistem air mengalir dengan debit $1 \mathrm{~L} /$ menit. Dua 
minggu setelah pemupukan, bentos siap dipanen dengan jumlah $1,5-2,5 \mathrm{~kg}$ bobot basah setiap kali panen. Pemanenan dilakukan dengan cara menyipon bentos dari jaring dan dasar bak, ditampung dengan saringan plankton net berukuran 30 mikron. Selanjutnya hasil saringan diperas hingga terbentuk padatan diatom dan siap diberikan sebagai pakan benih teripang.

Pada pemeliharaan larva teripang hingga mencapai umur satu bulan, biasanya telah menghasilkan juvenil yang mempunyai ukuran pajang $0,2 \mathrm{~cm}$. Juvenil teripang pada ukuran tersebut telah siap memangsa pakan alami (bentos) yang tersedia di bak pendederan.

Wadah pendederan yang digunakan untuk pemeliharaan juvenil merupakan bak fiber dengan ukuran 2,0 m x 1,5 m x $07 \mathrm{~m}$ dan bak pemeliharaan ini sebaiknya ditempatkan outdoor. Menjelang dua minggu sebelum juvenil dipanen, sebaiknya dipersiapkan bak pendederan yang telah dipasang jaring berbentuk segi empat ukuran $1,0 \mathrm{~m} \times 0,7 \mathrm{~m} \times 0,5 \mathrm{~m}$ dan terbuat dari kain kasa untuk menumbuhkan pakan alami (bentos). Kepadatan juvenil untuk setiap jaring sebanyak 500 individu ukuran 2-3 mm per jaring dan jumlah jaring dalam dalam satu bak sebanyak dua buah. Pemberian pakan dilakukan pada sore hari dengan dosis $2 \%$ dari bobot biomassa. Penyiponan rutin dilakukan setiap hari dan juga selama pemeliharaan dengan sistem air mengalir dengan debit $1 \mathrm{~L} /$ menit.

\section{Analisis Keragaman Genetik Teripang Pasir}

Tahapan untuk analisis keragaman genetik pada benih teripang pasir diawali dengan ekstraksi dan purifikasi DNA genom, amplifikasi genom menggunakan PCR konvensional, separasi hasil PCR, dan analisis data dengan software Arlequin.

\section{Isolasi DNA genom}

DNA teripang pasir diisolasi dari bagian daging dengan menggunakan extraction BlackPrep Rodent Tail DNA kit (Analytic Jena). Daging teripang bersifat kenyal sehingga sulit untuk dihancurkan. Oleh sebab itu, sebelum diekstraksi, terlebih dahulu daging teripang dibekukan dengan menggunakan dry Ice. Dengan cara ini, daging teripang dapat dihancurkan dengan menggunakan mortar. DNA genom diisolasi dan dipurifikasi sesuai dengan protokol standar dari kit yang digunakan.

\section{Analisis Mikrosatelit (Simple Sequence Repeats)}

Tiga lokus mikrosatelit dipilih dari 18 lokus yang dapat menghasilkan amplifikasi pita yang jelas, reproduksibilitasnya baik, dan relatif stabil setelah dilakukan optimasi suhu annealing (Tabel 1). Selanjutnya untuk dapat mendeteksi fragmen mikrosatelit pada genetic analyzer diperlukan pelabelan dengan bahan fluorescent pada salah satu dari sepasang primer pada ujung $5^{\prime}$.

\section{Elektroforesis}

Setiap produk PCR selain diseparasi menggunakan gel agarose 1,0\%dalam $1 \times$ bufer TBE, juga dipisahkan secara otomatis menggunakan mesin sequencer $A B I$ PRISM 3730xI Genetic Analyzer.

\section{Genotipe Pita SSR}

Setiap pita yang dihasilkan diinterpretasikan sebagai alel, dan dibuat tabel data genotipe. Untuk memperoleh nilai keragaman genetik meliputi keragaman alel dan heterozigositas, maka data dari hasil genotipe diolah menggunakan software Arlequin versi 3.5 (Excoffier \& Lischer, 2010).

Tabel 1. Sekuens tiga primer SSR pada teripang pasir, Holothuria scabra Table 1. Sequence of three SSR primers of sea cucumber, Holothuria scabra

\begin{tabular}{ccc}
\hline $\begin{array}{c}\text { Primer } \\
\text { Primer }\end{array}$ & $\begin{array}{c}\text { Urutan basa (5'-3') } \\
\text { Base Sequence (5'-3') }\end{array}$ & $\begin{array}{c}\text { Fragmen } \\
\text { Fragment (bp) }\end{array}$ \\
\hline Hsc 28 & F : 5'-/5HEX/TTCTGGTCTCGACTGGCAC-3' \\
R : TCAGTATCGGCTCCACAGG & $217-484$ \\
\hline Hsc 49 & F : 5'-/56 TAMN/TGAGCACGGTGTATTGTCC-3' & $157-237$ \\
\hline Rsc 59 & F : 5'-/56-ROXN/AGAGCACACGTATCCCCAC-3' & $234-264$ \\
\hline
\end{tabular}

Sumber (Source): Fitch et al. (2012) 


\section{HASIL DAN BAHASAN}

\section{Pembenihan Teripang Pasir}

Jumlah induk yang digunakan dalam proses perbenihan sebanyak 20 ekor per lokasi. Ukuran ratarata panjang dan bobot total induk dari lokasi Maluku Tenggara lebih besar dibandingkan dengan induk dari kedua lokasi lainnya (Gambar 1).

Pada Gambar 1, terlihat bahwa ukuran rata-rata panjang dan bobot total induk dari Maluku Tenggara mencapai $14,64 \pm 1,80 \mathrm{~cm} ; 186,61 \pm 6,03 \mathrm{~g}$; diikuti dengan induk dari Sulawesi Selatan mempunyai ukuran panjang 12,08 $\pm 2,22 \mathrm{~cm}$ dan bobot 125,76 $\pm 8,05 \mathrm{~g}$; serta induk dari Bali hanya mempunyai ukuran panjang $10,79 \pm 1,39 \mathrm{~cm}$ dan bobot 78,47 $\pm 10,23 \mathrm{~g}$.

Dilihat dari ukuran induk yang diperoleh, induk yang berasal dari di Bali (Pantai Pejarakan) tergolong kecil karena kemungkinan besar telah mengalami over fishing sehingga individu yang ada belum mencapai ukuran maksimum tetap dipanen. $\mathrm{Hal}$ ini mengindikasikan adanya tingkat ekspoitasi yang tinggi pada teripang di daerah Bali khususnya di Pantai Pejarakan bila dibandingkan dengan beberapa tahun yang lalu ukuran induk masih berkisar antara $250 \mathrm{~g}$ hingga $300 \mathrm{~g}$ (Moria et al., 1997). Di samping itu, teripang hidup di padang lamun yang dangkal sehingga memudahkan masyarakat untuk melakukan penangkapan. Uthicke et al. (2009) dan Launey \& Hedgecock (2001) menyatakan bahwa intensitas penangkapan yang tinggi, selain menyebabkan penurunan populasi dalam hal ukuran dan jumlah, juga secara proporsional akan berdampak terhadap penurunan keragaman genetik dari populasi tersebut.

Pemijahan induk teripang pasir dari tiga lokasi sumber induk telah berhasil dilakukan melalui kejutan suhu menggunakan alat heater. Suhu air dinaikkan hingga $30^{\circ} \mathrm{C}$, oleh karena itu induk yang baru ditransportasikan dengan suhu rata-rata $26^{\circ} \mathrm{C}-27^{\circ} \mathrm{C}$ sangat cocok untuk langsung dilakukan pemijahan. Data pemijahan yang meliputi jumlah telur, daya tetas telur, sintasan larva sampai juvenil ukuran $2 \mathrm{~mm}$, dan dari juvenil sampai benih ukuran $4-5 \mathrm{~cm}$ disajikan pada Tabel 2.

Dari Tabel 2 tampak bahwa induk yang berasal dari Maluku Tenggara memberikan nilai yang tinggi dalam hal jumlah telur, daya tetas, dan sintasan, diikuti dengan induk dari Sulawesi Selatan dan Bali. Hal ini menunjukkan bahwa induk dari Bali sebenarnya belum siap untuk dijadikan induk dibandingkan induk dari dua lokasi lainnya, hal ini terlihat dari performa benih yang dihasilkan (Gambar 2).

Berdasarkan Gambar 2 tampak bahwa pada umur 170 hari (enam bulan) benih dari induk teripang Maluku Tenggara sudah mencapai ukuran panjang dan bobot rata-rata 5,67 $\pm 0,76 \mathrm{~cm} ; 13,26 \pm 5,63 \mathrm{~g}$ dengan ukuran panjang terkecil 4,67 $\mathrm{cm}$ dan terbesar 6,46 $\mathrm{cm}$; sedangkan untuk ukuran bobot yang terendah

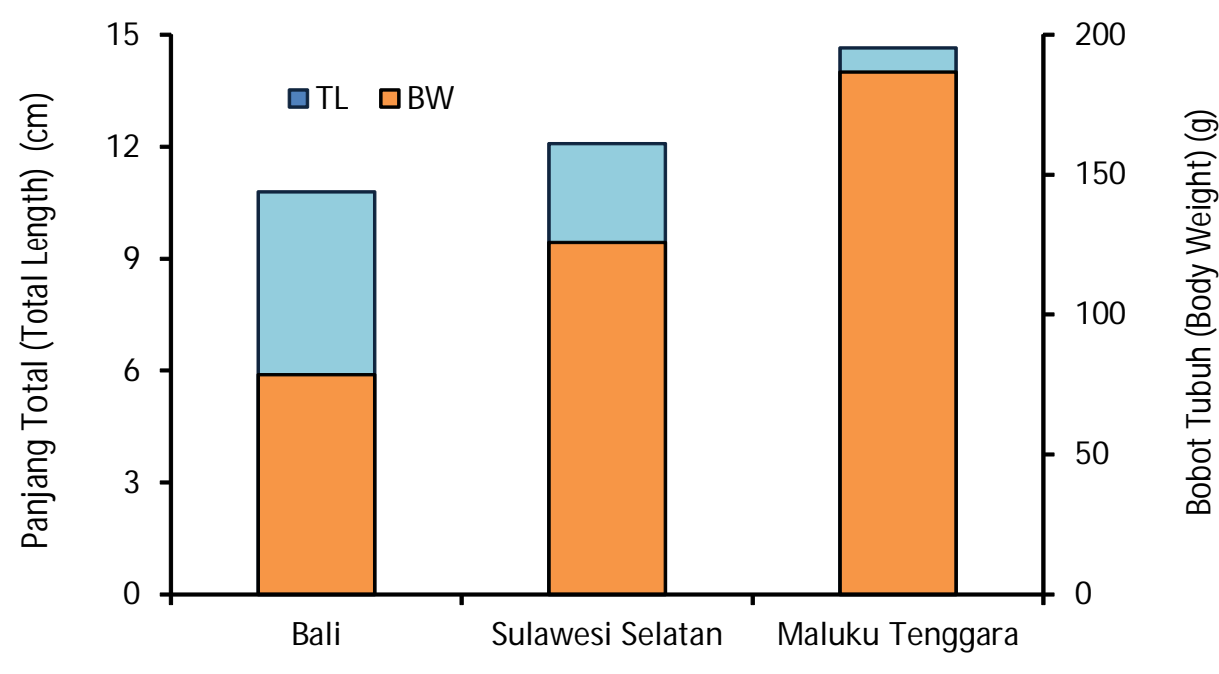

Lokasi induk (Broodstock Location)

Gambar 1. Panjang dan bobot induk teripang pasir dari perairan yang berbeda dan digunakan dalam perbenihan

Figure 1. Length and body weight of sea cucumber Holothuria scabra broodstock from different locations used for seed production 
Tabel 2. Jumlah telur, daya tetas, dan sintasan larva sampai juvenil (ukuran $0,2 \mathrm{~cm}$ ), juvenil ukuran $4-5 \mathrm{~cm}$ dari pemijahan induk teripang pasir, H. scabra dari sumber yang yang berbeda

Table 2. Number of eggs, hatching rate and survival rate of juvenile $(0.2 \mathrm{~cm})$, juvenile $4-5 \mathrm{~cm}$ from spawning of sea cucumber Holothuria scabra broodstock from different locations used in this research

\begin{tabular}{|c|c|c|c|c|c|c|}
\hline \multirow{2}{*}{$\begin{array}{l}\text { Asal induk } \\
\text { Source of } \\
\text { broodstock }\end{array}$} & \multicolumn{2}{|c|}{$\begin{array}{l}\text { Ukuran induk } \\
\text { Broodstock size }\end{array}$} & \multirow{2}{*}{$\begin{array}{c}\text { Jumlah telur/ } \\
\text { induk } \\
\text { Number of eggs/ } \\
\text { broodstock }\end{array}$} & \multirow{2}{*}{$\begin{array}{c}\text { Daya } \\
\text { tetas } \\
\text { Hatching } \\
\text { rate }\end{array}$} & \multirow{2}{*}{$\begin{array}{c}\text { Sintasan } \\
\text { larva - } \\
\text { juvenil } 0.2 \mathrm{~cm} \\
\text { Larval to } \\
\text { juvenile } 2 \mathrm{~mm} \\
\text { survival rate }(\%)\end{array}$} & \multirow{2}{*}{$\begin{array}{c}\text { Sintasan dari } \\
\text { juvenil } 0,2 \mathrm{~cm} \\
\text { sampai ukuran } 4-5 \mathrm{~cm} \\
\text { Juvenile } \\
2 \mathrm{~mm} \text { to } 4-5 \mathrm{~cm} \\
\text { survival rate }(\%)\end{array}$} \\
\hline & $\begin{array}{c}\text { Panjang total } \\
\text { Total length }(\mathrm{cm})\end{array}$ & $\begin{array}{l}\text { Bobot badan } \\
\text { Body weight (g) }\end{array}$ & & & & \\
\hline $\begin{array}{l}\text { Bali } \\
\text { Bali }\end{array}$ & $10.79 \pm 1.39$ & $78.47 \pm 20.24$ & 270.000 & 35.0 & 0.63 & 50 \\
\hline $\begin{array}{l}\text { Sulawesi Selatan } \\
\text { South Sulawesi }\end{array}$ & $12.08 \pm 2.22$ & $125.76 \pm 38.81$ & 530.000 & 53.0 & 0.94 & 65 \\
\hline $\begin{array}{l}\text { Maluku Tenggara } \\
\text { Southeast M oluccas }\end{array}$ & $14.64 \pm 1.80$ & $186.61 \pm 74.68$ & 620.000 & 76.0 & 0.93 & 80 \\
\hline
\end{tabular}

sebesar 7,40 g dan yang tertinggi 18,5 g. Selanjutnya diikuti benih dari induk Sulawesi Selatan sebesar 4,75 $\pm 0,91 \mathrm{~cm} ; 6,3 \pm 2,22 \mathrm{~g}$ dengan ukuran panjang terkecil dan terbesar berturut-turut 3,07 cm dan 5,94 $\mathrm{cm}$; serta ukuran bobot 3,50 g dan 7,40 g. Benih dari induk Bali dengan umur yang sama mencapai ukuran panjang dan bobot sebesar 4,85 $\pm 0,64 \mathrm{~cm} ; 6,2 \pm$ $3,6 \mathrm{~g}$ dengan ukuran panjang sebesar $4,06 \mathrm{~cm}$ and $5,08 \mathrm{~cm}$ pada panjang; serta 3,5 g dan 10,6 g untuk bobot. Di samping pertumbuhan yang lebih cepat, benih dari induk Maluku Tenggara memiliki warna kulit lebih cerah dan sintasan juga lebih tinggi. Secara visual, tampak bahwa benih dari induk Maluku Tenggara lebih sehat dibandingkan dengan benih dari dua lokasi lainnya.

Hasil analisis statistik menunjukkan bahwa pertumbuhan panjang total pada ketiga juvenil F-1 dari ketiga sumber induk yang berbeda tidak berbeda nyata $(P>0,05)$. Sedangkan pada pertumbuhan bobot badan,

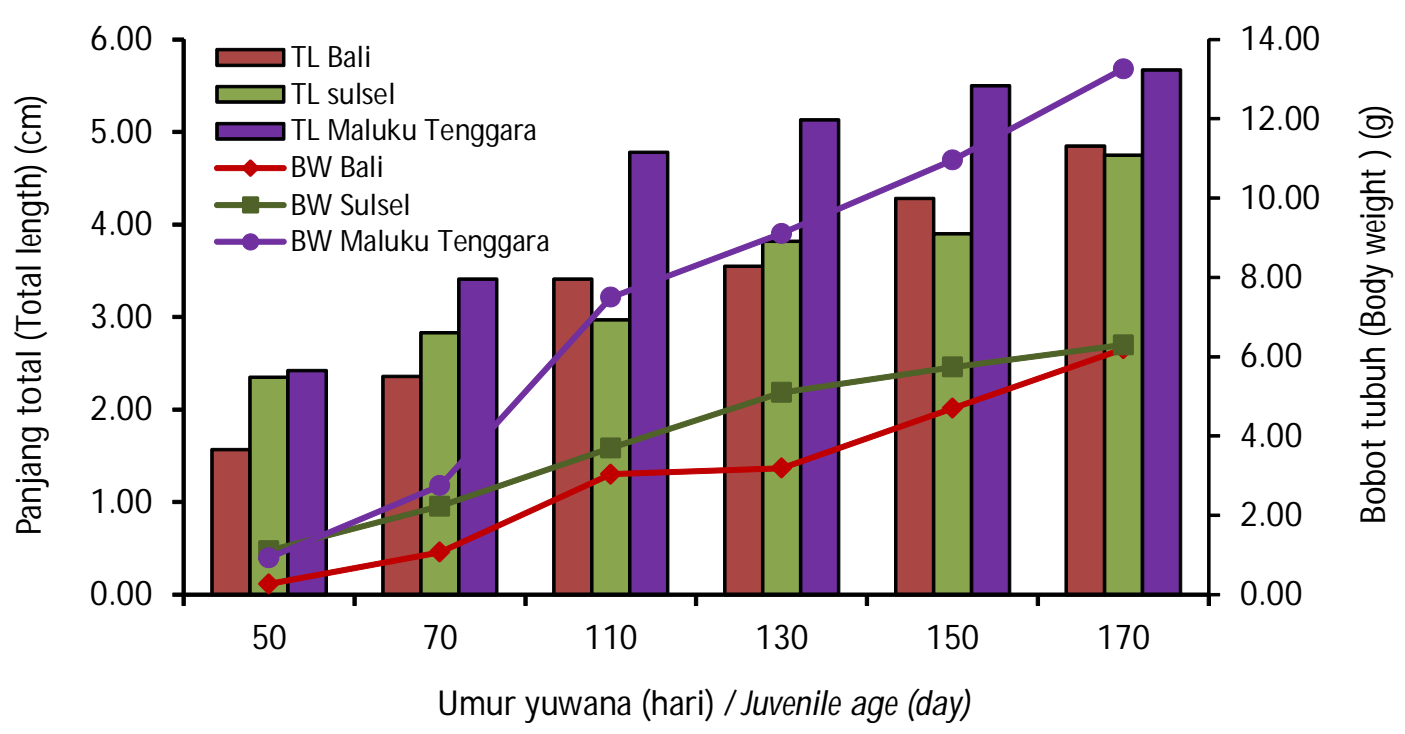

Gambar 2. Pertumbuhan juvenil (F-1) teripang pasir dari sumber induk yang berbeda (Maluku Tenggara, Sulawesi Selatan, dan Bali)

Figure 2. Growth pattern of sea cucumber Holothuria scabra juvenile (F-1) from different locations of broodstock (Southeast Moluccas, South Sulawesi, and Bali) 
dari hasil uji lanjut Tukey test menunjukkanbahwa perbedaan yang nyata antara juvenil F-1 Bali dan Sulawesi Selatan terhadap juvenile F-1 Maluku Tenggara $(\mathrm{P}<0,05)$.

Modifikasi yang telah dilakukan dalam proses pembenihan teripang pasir pada saat ini dibandingkan dengan proses pembenihan pada tahun 1994-1998 adalah pakan yang diberikan pada saat pemeliharaan juvenil ukuran $2 \mathrm{~mm}$ sampai benih ukuran $4-5 \mathrm{~cm}$ diberi pakan alami berupa diatom bentos. Dengan penggunaan pakan alami ini, benih teripang ukuran 0,2 cm dapat mencapai ukuran 4-5 cm dalam waktu tiga bulan dibandingkan dengan menggunakan kelekap hasil tambak yang membutuhkan waktu 5-6 bulan untuk mencapai ukuran seperti tersebut (Sembiring et al., 2004).

\section{Keragaman Genetik Teripang Pasir}

Dari tiga lokus mikrosatelit yang digunakan (Hsc-28, Hsc-49, dan Hsc-59), diperoleh produk amplifikasi dengan rata-rata jumlah alel sebesar 1,6672,000 dengan frekuensi alel seperti terlihat pada Tabel 3. Menurut Nei (1987), nilai He (heterozigositas expected) sering diidentikkan dengan keragaman genetik dan Ho (heterozigositas observed) sering dianggap tidak terlalu penting jika dijadikan pembanding dari keragaman genetik karena terpengaruh oleh inbreeding dan proses evolusi lainnya (Berg \& Hammrick, 1997).
Berdasarkan Tabel 3, rerata dari nilai Ho dan He secara berurutan pada populasi induk dari Bali adalah 0,278 dan 0,366; induk dari Sulawesi Selatan sebesar 0,278 dan 0,449; dan induk dari Maluku Tenggara adalah 0,389 dan 0,292 . Nilai rata-rata Ho dan He pada induk teripang pasir tersebut mempunyai nilai yang mirip dengan hasil penelitian Kanno \& Kijima (2003) pada teripang, $\mathrm{S}$. japonicus dengan nilai rata-rata $\mathrm{Ho}=0,26$ dan $\mathrm{He}=0,27$. Rasio $\mathrm{Ho} / \mathrm{He} \geq 1$ mengindikasikan bahwa populasi teripang tersebut mempunyai rasio variasi genetik yang tinggi. Dari pengamatan nilai rasio Ho/He pada ketiga populasi, ternyata populasi induk dari Sulawesi Selatan mempunyai nilai rasio < 1 $(0,619)$ sedangkan populasi induk dari Maluku Tenggara dan Bali, nilai rasio $\geq 1$.

Dilihat dari hasil AMOVA dengan software Arlequin versi 3.5, masih menunjukkan adanya sebaran keragaman genetik di antara populasi induk teripang dari ketiga lokasi tersebut (Tabel 4).

Berdasarkan Tabel 4, variasi antara populasi teripang pasir dari Bali, Sulawesi Selatan dan Maluku Tenggara sebesar $24,75 \%$ Sementara, nilai variasi individu dalam populasi teripang pasir dari Bali, Sulawesi Selatan, dan Maluku Tenggara sebesar 17,63\% sedangkan besarnya variasi antar individu adalah $57,63 \%$ Hasil perhitungan F-statistics berupa nilai $F_{1 S^{\prime}}$ $\mathrm{F}_{\mathrm{ST}}$, dan $\mathrm{F}_{\mathrm{IT}}$ secara berurutan adalah 0,$2342 ; 0,2475$; dan 0,4237 . Nilai $F_{15}$ tersebut menunjukkan besarnya laju inbreeding (perkawinan sekerabat) oleh individu

Tabel 3. Keragaman genetik induk teripang pasir yang dianalisis dengan tiga lokus mikrosatelit

Table 3. Genetic variation of sea cucumber broodstock analyzed with three microsatellite locus

\begin{tabular}{lcccc}
\hline \multicolumn{1}{c}{$\begin{array}{c}\text { Lokasi } \\
\text { Location }\end{array}$} & $\begin{array}{c}\text { Lokus } \\
\text { Loci }\end{array}$ & $\begin{array}{c}\text { Jumlah alel } \\
\text { Number of allele }\end{array}$ & Ho & He \\
\hline \multirow{3}{*}{ Bali } & Hsc-28 & 2 & 0.667 & 0.500 \\
Bali & Hsc-49 & 2 & 0.167 & 0.153 \\
& Hsc-59 & 2 & 0.000 & 0.444 \\
\cline { 2 - 5 } & Rata-rata (Average) & $\mathbf{2 . 0 0}$ & $\mathbf{0 . 2 7 8}$ & $\mathbf{0 . 3 6 6}$ \\
\hline \multirow{4}{*}{ Sulawesi Selatan } & Hsc-28 & 2 & 0.167 & 0.375 \\
South Sulawesi & Hsc-49 & 2 & 0.167 & 0.486 \\
& Hsc-59 & 2 & 0.500 & 0.486 \\
\cline { 2 - 5 } & Rata-rata (Average) & $\mathbf{2 , 0 0 0}$ & $\mathbf{0 . 2 7 8}$ & $\mathbf{0 . 4 4 9}$ \\
\hline \multirow{3}{*}{ Maluku Tenggara } & Hsc-28 & 1 & 0.000 & 0.000 \\
Southeast Moluccas & Hsc-49 & 2 & 0.667 & 0.500 \\
& Hsc-59 & 2 & 0.500 & 0.375 \\
\cline { 2 - 5 } & Rata-rata (Average) & $\mathbf{1 , 6 6 7}$ & $\mathbf{0 . 3 8 9}$ & $\mathbf{0 . 2 9 2}$ \\
\hline
\end{tabular}


Tabel 4. Analysis of molecular variance (AMOVA) dari tiga populasi teripang pasir, H. scabra menggunakan tiga lokus mikrosatelit

Table 4. Analysis of molecular variance (AM OVA) from three broodstock sea cucumber, H. scabra population by using three microsatellite locus

\begin{tabular}{lccc}
\hline \multicolumn{1}{c}{$\begin{array}{c}\text { Sumber variasi } \\
\text { Source of variation }\end{array}$} & $\begin{array}{c}\text { Jumlah square } \\
\text { Sum of squares }\end{array}$ & $\begin{array}{c}\text { Komponen varian } \\
\text { Variance components }\end{array}$ & $\begin{array}{c}\text { Persentase variasi } \\
\text { Percentage variation (\%) }\end{array}$ \\
\hline $\begin{array}{l}\text { Antar populasi } \\
\text { Among population } \\
\text { Antar individual dalam populasi }\end{array}$ & 6,389 & 0.20278 & 24.75 \\
$\begin{array}{l}\text { Among individuals within populations } \\
\text { Di dalam populasi } \\
\text { Within populations }\end{array}$ & 11,417 & 0.14444 & 17.63 \\
\hline \multicolumn{1}{c}{ Total } & 8,500 & 0.47222 & 57.63 \\
\hline$F_{\text {IS }}=0.2342(23.42 \%)$ & 26,306 & 0.81944 & \\
\hline$F_{I T}=0.4237(42.37 \%)$ & & & \\
\hline$F_{S T}=0.2475(24.75 \%)$ & & & \\
\hline
\end{tabular}

yang terjadi pada suatu sub-populasi sebesar $23,4 \%$ Nilai $F_{I T}$ tersebut menunjukkan tingkat keseluruhan dari inbreeding yang terjadi pada total populasi berkisar $42,4 \%$ Nilai $F_{S T}$ menunjukkan derajat inbreeding pada sub-populasi dari total populasi sebesar $24,8 \%$ Berdasarkan nilai $F_{S T}$ tersebut dapat diketahui bahwa belum terjadi diferensiasi (pemisahan) genetik antara populasi teripang pasir dari Bali, Sulawesi Selatan, dan Maluku Tenggara. Indeks fiksasi $\left(\mathrm{F}_{\mathrm{ST}}\right)$ merupakan ukuran diferensiasi genetik antar populasi, di mana apabila nilai $F_{s T}$ adalah nol menunjukkan bahwa tidak ada perbedaan secara genetik dari populasi-populasi yang diamati, sedangkan nilai 1,0 diartikan bahwa ada perbedaan karakter genetik (Excoffier \& Lischer, 2010).

Keragaan genotipe pada induk dari perairan yang berbeda (Bali, Sulawesi Selatan, dan Maluku Tenggara) dapat tergambarkan kesesuaian fenotipe dengan baik pada benih yang dihasilkan. Dari hasil yang diperoleh terlihat bahwa fenotipe benih teripang dari Maluku Tenggara yang ditunjukkan dari ukuran bobot $(186,61$ $\pm 74,68 \mathrm{~g}$ ) mempunyai korelasi dengan sifat genotipe induknya dengan sifat heterozigositas yang tinggi $(0,389)$. Demikian pula terjadi pada benih yang dihasilkan dari induk Bali dan Sulawesi Selatan. Hal ini dapat juga diterangkan dengan nilai Coeficient Variasi (CV), yaitu indeks untuk menentukan variasi morfologi antar hewan uji atau benih yang dihasilkan. Jika CV $(\Delta)$ tinggi, ini berarti sifat morfologi (fenotipe) sama dengan sifat genetik (genotipe), yaitu $\Delta \mathrm{G}=\Delta \mathrm{P}$ $+\Delta \mathrm{E}(\Delta \mathrm{G}$ : variasi genotipe; $\Delta \mathrm{F}$ : variasi fenotip, $\Delta \mathrm{E}$ : variasi lingkungan). Pada keadaan ini diasumsikan bahwa semua benih dipelihara dalam kondisi yang sama sehingga $\Delta \mathrm{E}=0$, dan akhirnya $\Delta \mathrm{G}=\Delta \mathrm{F}$. Dari hasil ini menunjukkan bahwa benih teripang yang mempunyai morfologi yang besar berkorelasi dengan sifat genetik yang lebih baik.

Informasi mengenai struktur populasi teripang di alam sampai saat ini belum ada. Sementara itu, penangkapan teripang di alam dilakukan secara kontinu sehingga informasi yang telah diperoleh mengenai keragaman genetik induk teripang, laju inbreeding dan diferensiasi genetik sangat berharga untuk pengembangan budidaya teripang yang berkelanjutan. Menurut Frankham et al. (2002), keanekaragaman genetik suatu organisme sangat penting dalam mempertahankan populasi sejak masa lalu, masa kini, dan masa depan. Pemeliharaan keanekaragaman genetik adalah kunci bagi sintasan jangka panjang dari spesies tersebut. Oleh sebab itu, diversitas genetik merupakan salah satu informasi penting dalam serangkaian proses awal mengevaluasi potensi genetik teripang pasir untuk kepentingan pengembangan, pemanfaatan, dan konservasi secara berkelanjutan.

Mengingat populasi teripang yang semakin menurun setiap tahunnya, serta pembenihan dan budidaya teripang yang belum berkembang, maka adanya inbreeding (perkawinan kerabat) yang menjadikan populasi lebih rentan terhadap kepunahan. Oleh karena itu, perlu dieksplor sumber daya genetik (SDG) dari lokasi lainnya yang masih memiliki relatif cukup banyak teripang pasir khususnya di perairan wilayah timur Indonesia. Hal ini perlu dilakukan karena keragaman genetik berdasarkan jumlah dan frekuensi alel untuk masing-masing populasi (Tabel 3) relatif 
rendah, walaupun metode analisis sudah menggunakan mikrosatelit (SSR) dengan tiga target lokus.

\section{KESIMPULAN}

Performa pertumbuhan panjang dan bobot benih teripang pasir dari induk Maluku Tenggara lebih tinggi dibandingkan dengan benih dari induk Sulawesi Selatan dan Bali pada umur yang sama. Keragaman genetik di antara ketiga populasi induk teripang tersebut tidak berbeda nyata ( $F s t=0,2475$ ) dengan nilai inbreeding yang terjadi pada total populasi induk teripang pasir lebih tinggi dari laju nilai inbreeding pada sub-populasi. Benih teripang yang mempunyai morfologi yang besar berkorelasi dengan sifat genetik yang lebih baik.

\section{DAFTAR ACUAN}

Akamine, J. (2000). Sea cucumbers from the coral reef to the world market. In Ushijima, I., \& Zayas, C.N. (Eds.). Bisayan knowledge, movement and identity. Quezon City. Philippines, p. 223-244.

Berg, E.E., \& Hamrick, J.L. (1997). Quantification of genetic diversity at allozyme loci. Conservation Journal for Rescue, 27, 415-424.

Bussarawit, S., \& Thongtham, N. (1999). Sea cucumber fisheries and trade in Thailand. Proc. International Conference: The conservation of sea cucumbers in Malaysia, their taxonomy, ecology and trade. Kuala Lumpur. Malaysia, p. 26-36.

Conand, C., \& Byrne, M. (1993). A review of recent developments in the world sea cucumber fisheries. Marine Fisheries Review, 55(4), 1-13.

Desvignes, J.F., Laroche, J., Durand J.D., \& Bouvet, Y. (2001). Genetic variability in reared stocks of common carp (Cyprinus carpio L.) based on allozymes and microsatellites. Aquaculture, 194, 291-301.

Excoffierd, L., \& Lischer, H.E. (2010). Arlequin suite ver 3.5: a new series of programs to perform population genetic analysis under Linux and Windows. Mol. Ecol. Resour., 10, 564-567.

Fitch, A.J., Leeworthy, G., Li, X., Bowman, W., Turner, L. \& Gardner, M.G. (2012). Isolation and characterisation of eighteen microsatellite markers from the sea cucumber, Holothuria scabra (Echinodermata: Holothuriidae). Australian Journal of Zoology, 60, 368-371.

Frankham, R., Briscoe, D.A., \& Ballou, J.D. (2002). Introduction to conservation genetics. $4^{\text {th }} \mathrm{Ed}$. Cambridge Unikversity Press. New York, 617 pp.
Kanno, M., \& Kijima, A. (2003). Genetic differentiation among three color variants of Japanese sea cucumber, Stichopus japonicus. Fish Sci., 694, 806812.

Launey, S., \& Hedgecock, D. (2001). High genetic load in the Pacific oyster Crassostrea gigas. Genetics, $159,255-265$.

Leary, R.F., Allendrof, F.W., \& Knudsen, K.L. (1985). Development instability and high meristic counts in interspesific hybrid of Salmonid fishes. Evolution, 39(6), 1318-1326.

Makatutu, D., Yunus, \& Rusdi, I. (1993). Penggunaan beberapa jenis pakan alami terhadap pertumbuhan dan sintasan larva teripang pasir, Holothuria scabra. Jurnal Penelitian Budidaya Pantai, 9(3), 97-102.

Moria, S.B., Setiawati, K.M., \& Darmansyah. (1997). Pendugaan musim pemijahan teripang pasir, Holothuria scabra di Pantai Pejarakan Bali Utara. Prosiding II Seminar Nasional Biologi XV. hlm. 815818.

Moria, S.B., Sugama, K., Suastika, M., \& Darmansyah. (1998). Pengaruh jenis shelter terhadap pertumbuhan dan sintasan larva teripang pasir, Holothuria scabra. Jurnal Penelitian Perikanan Indonesia, 4(3), 32-36.

Nei, M. (1987). Molecular evolutionary genetics. Columbia Press. New York, 512 pp.

Reichenbach, N., \& Holloway. (1995). Potential for asexual propagation of several commercial important species of tropical sea cucumber (Echinodermata). Journal of theW orld AquacultureSociety, 26(3), 272-278.

Sembiring, S.B.M., Sugama, K., Suastika, I M., Makatutu, D., \& Jufri. (2004). Pedoman teknis teknologi perbenihan teripang pasir, Holothuria scabra. Pusat Riset Perikanan Budidaya, Badan Riset Kelautan dan Perikanan. Departemen Kelautan dan Perikanan. Jakarta, $23 \mathrm{hlm}$.

Sugama, K., Taniguchi, N., \& Umeda, S. (1988). An experimental study on genetic drift in hatchery population of red sea bream. Bull. Japan Sci. Soc., 54, 739-744.

Uthicke, S., Schaffelke, B., \& Byrne, M. (2009). A boom-bust phylum? Ecological and evolutionary consequences of density variations in echinoderms. Ecological Monographs, 79, 3-24. 